\title{
Zabudowa mieszkaniowa doliny gruvedalen w Longyearbyen na Spitsbergenie jako przykład przestrzeni społecznej na terenie o ekstremalnie zimnym klimacie
} Housing development of gruvedalen in Longyearbyen, Spitsbergen, as a case of a social space in an area with an extreme cold climate

\begin{abstract}
Streszczenie:
W niniejszej pracy jako główny przedmiot badań została wybrana przestrzeń społeczna zabudowań mieszkaniowych doliny Gruvedalen w Longyearbyen na terenie wyspy Spitsbergen w archipelagu Svalbard. Jest to przykład przestrzeni społecznej nietypowej dla europejskich warunków. Jest ona bowiem zlokalizowana na terenie o ekstremalnie zimnym klimacie. Analizując architekturę i urbanistykę Spitsbergenu, a także jego mieszkańców, zwrócono uwagę na rolę i znaczenie przestrzeni społecznych w życiu mieszkańców, ich ogólną charakterystykę, pozytywy, negatywy, sposób wykorzystywania przez różne grupy społeczne oraz jakość i rozwiązania funkcjonalne. W pracy badawczej zastosowano badania teoretyczne, badania terenowe in situ, autorską relację oraz badania ankietowe. Przestrzenie wspomagają prawidłowe funkcjonowanie środowiska mieszkaniowego, pozwalają na poczucie bezpieczeństwa rezydentów i odwiedzających. Najważniejszym czynnikiem wpływającym na odbiór i kształtowanie przestrzeni społecznych przez mieszkańców północnych krańców świata jest forma architektoniczna, lokalizacja i powiązanie z kontekstem, otoczeniem.
\end{abstract}

\begin{abstract}
:
The primary object of this study is the common space of a housing development found in Gruvedalen Valley in Longyearbyen, on the island of Spitsbergen, a part of the Svalbard Archipelago. It is a case of a social space that is atypical of European conditions. It is located in a territory with an extremely cold climate. When analysing the architecture and urban layouts of Spitsbergen, as well as its residents, I noted the role and significance of social spaces in their lives, and provided their general overview, which includes the positives, negatives and manner of use by various social groups, in addition to its quality and functional solutions. The research methods used in the study include: theoretical research, in situ field research, original report, and a survey. Social spaces support the correct functioning of the housing environment and enhance the sense of safety among residents and visitors. The most crucial factors that affects the reception and design of social spaces by residents are: architectural form, its location and linkages with the context and surroundings.
\end{abstract}

Słowa kluczowe: Svalbard, Spitsbergen, Longyearbyen, Gruvedalen, przestrzeń społeczna

Keywords: Svalbard, Spitsbergen, Longyearbyen, Gruvedalen, social space

\section{WSTĘP}

Przestrzenie społeczne to nieodłączny element kształtujący urbanistykę miasta i jego mieszkańców. Wytworzona dzięki nim spójna jednostka pozwala na stworzenie środowiska przyjaznego użytkownikom. Niezależnie od lokalizacji na świecie, klimatu, zastanego kontekstu, istotnym problemem w kształtowaniu przestrzeni spo-

\section{INTRODUCTION}

Social spaces are an inseparable element of shaping a city's urban layout and its residents. The cohesive units that they can produce allow for creating a user-friendly environment. Regardless of location, climate, or pre-existing context, complex integration processes that occur between individuals and so- 
łecznych są złożone procesy integracji zachodzące pomiędzy jednostkami i grupami społecznymi. Wnętrza przestrzeni społecznych w przewadze urbanistyczne, w mniejszej części architektoniczne, przybierają różne formy, dając poczucie bezpieczeństwa, pozwalają zaspokoić podstawowe potrzeby społeczeństwa do kontaktów międzyludzkich, przynależności, identyfikacji, akceptacji, szacunku, rozwoju, spójności i odpowiedzialności za daną przestrzeń. (Schneider-Skalska, 2012, s. 6-9)

Czynniki wpływające na kreowanie przestrzeni społecznych miast, w których występują skrajne warunki klimatyczne i atmosferyczne są często inne i zaskakujące w stosunku do przestrzeni miejskich w klimacie umiarkowanym lub zbliżonym do umiarkowanego.

\section{CEL, ZAKRES BADAŃ, METODA}

Praca opiera się na założeniu, że istnieje symbioza miasta i jego użytkowników kształtowana w przestrzeniach społecznych niezależnie od warunków klimatycznych. Ich różnica wynika jedynie ze spostrzeżenia, że przestrzenie te mają różne oblicza. Bez zaspokojenia potrzeb jednostki jak i grup mieszkańców nie byłoby możliwe stworzenie trwałej, prawidłowo funkcjonującej jednostki miejskiej. Jako główny przedmiot badań została wybrana przestrzeń społeczna powstała w latach 2003-2016, która znajduje się przy zabudowie mieszkaniowej w dzielnicy Gruvedalen w dolinie o tej samej nazwie w mieście Longyearbyen. Analizie poddano rozwiązania funkcjonalne, kontekst krajobrazowy, formę założenia architektonicznego, konstrukcję, zastosowane materiały, kolor i detal.

Badanie jest próbą odpowiedzi na pytanie czy w ekstremalnych warunkach klimatycznych, możliwe jest stworzenie dogodnych przestrzeni społecznych dla mieszkańców i turystów Spitsbergenu oraz jakie czynniki dotyczące kształtowania tych przestrzeni o tym decydują.

Dla prawidłowej oceny analizę przeprowadzono wielopoziomowo: od kontekstu krajobrazowego, urbanistycznego, jego otoczenia, skali, funkcji, formy założenia architektonicznego, konstrukcji, do zastosowanych materiałów, detalu, koloru.

Zastosowane w pracy metody badawcze to: badania teoretyczne, badania terenowe in situ, autorska relacja, badania ankietowe.

Uczestnikami badania ankietowego byli mieszkańcy miasta Longyearbyen na Spitsbergenie w przedziale wiekowym do 66 roku życia. 40\% wszystkich badanych stanowili mężczyźni. Najczęstsze odpowiedzi (75\%) uzyskano od grupy wiekowej w przedziale $26-44$ lata. 50\% odpowiadających mieszka w Longyearbyen więcej niż pięć lat, 30\% badanych mieszka w mieście między dwa a pięć lat, natomiast poniżej roku 15\%. 95\% odpowiadających utrzymuje dobre kontakty z pozostałymi mieszkańcami miasta.

\section{ARCHIPELAG SVALBARD}

Archipelag Svalbard jest jednym z najbardziej wysuniętych na północ zespołem wysp w Arktyce. Zlokalizowany jest ponad kołem podbiegunowym północnym, między $74^{\circ}$ i $81^{\circ}$ szerokości północnej oraz $10^{\circ}$ i $35^{\circ}$ długości geograficznej wschodniej. Łącznie jego powierzchnia wynosi 62405 km² (Szupryczyński, 1968, s. 8), a długość linii brzegowej jest równa $3587 \mathrm{~km} .{ }^{1}$ Wyspy położone są oko- cial groups are an essential issue in shaping social spaces. The interiors of social spaces, mostly urban and less often architectural, take on various forms, providing a sense of safety and allowing for the satisfaction of essential needs of society for interpersonal contact, belonging, identification, acceptance, respect, development, cohesion and responsibility for a given space (Schneider-Skalska, 2012, pp. 6-9). Factors that affect the design of urban social spaces in cities with extreme climate and atmospheric conditions are often different from and surprising relative to urban spaces in temperate or other similar climates.

\section{RESEARCH OBJECTIVE, SCOPE AND METHOD}

This study is based on the assumption that there exists a symbiosis between the city and its users that is shaped within social spaces, irrespective of climate conditions. The difference between them is based solely on the observation that these spaces take on different forms. Without satisfying the needs of the individual and groups of individuals, it would not be possible to create a lasting and correctly functioning urban unit. The primary object of this study is a social space located in a housing development in the Gruvedalen district, in a valley of the same name that is located in the town of Longyearbyen, established in the years 2003-2006. I analysed functional solutions, the landscape context, the form of the architectural layout, the structural system and the materials, colours and details applied.

This study is to answer the question as to whether it is possible to create suitable social spaces for residents and tourists in the cold climate conditions of Spitsbergen and which factors concerning the design of these spaces can determine this.

To properly assess this problem, I performed a multilevel analysis: starting with the landscape and urban context, the surroundings, scale, function and form of the architectural layout, the structural system, and the materials, details and colours applied.

The research methods used in the study include: theoretical research, in situ field research, original report, and a survey.

The survey covered a group of respondents comprised of the residents of Longyearbyen, Spitsbergen, aged up to 66 . Men formed $40 \%$ of the respondents. The most responses $(75 \%)$ were given by respondents aged 26-44. In terms of time spent living in Longyearbyen, $50 \%$ of the respondents reported they were living there for longer than five years, $30 \%$ were living there for a period of between two and five years, while $15 \%$ were living there for less than a year. The vast majority of respondents $(95 \%)$ stated that they maintained good relations with other residents of the town.

\section{THE SVALBARD ARCHIPELAGO}

The Svalbard Archipelago is one of the northernmost island groups in the Arctic. It is located beyond the Arctic Circle, at a latitude of between $74^{\circ}$ and $81^{\circ}$ north and a longitude of between $10^{\circ}$ and $35^{\circ}$ east. Its total area is $62,405 \mathrm{~km}^{2}$ (Szupryczyński, 1968, p. 8) and 


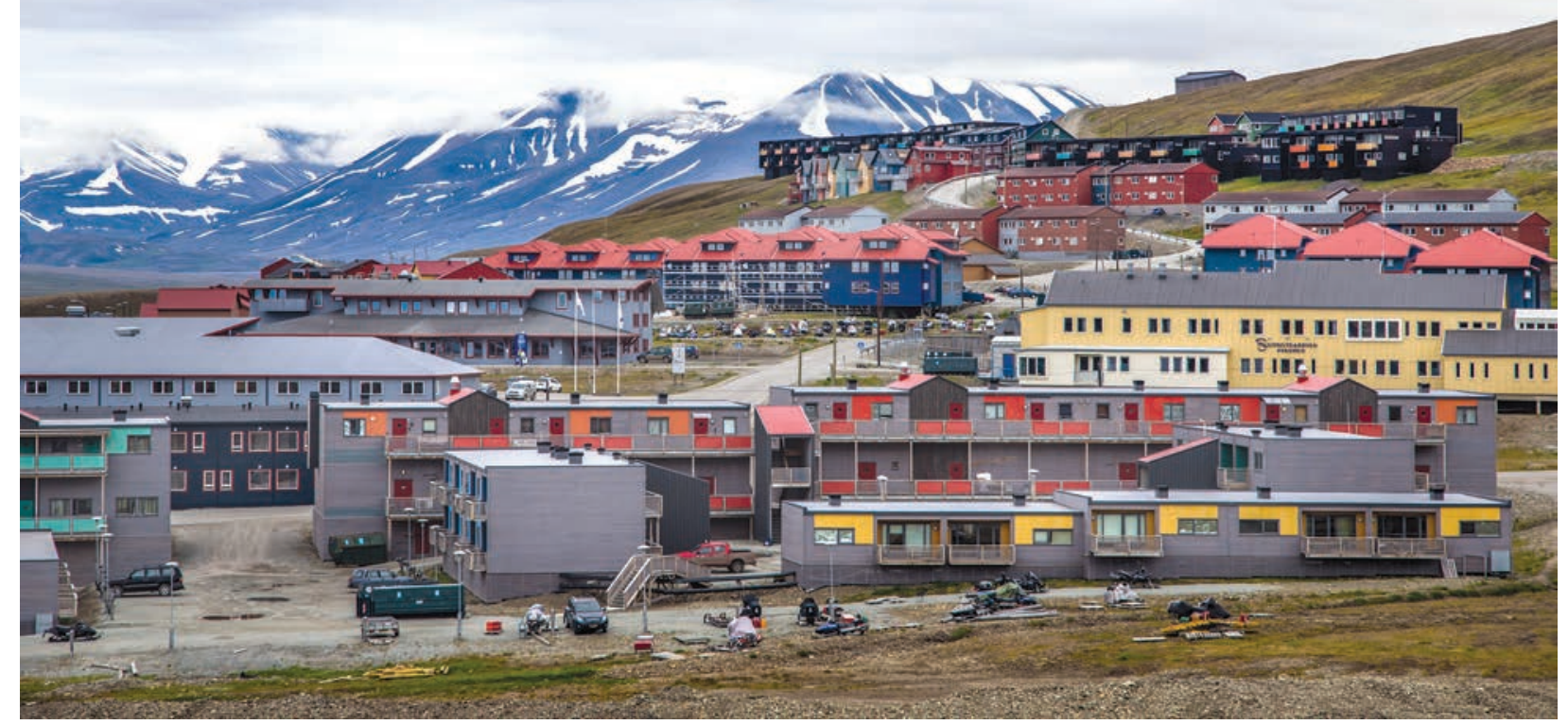

Fot. 1. Widok miasta Longyearbyen z widoczną zabudową doliny Gruvedalen w tle. fot. Agnieszka Żabicka, 2016

Photo 1. View of Longyearbyen with the development of Gruvedalen Valley in the background. Photo by Agnieszka Zabicka, 2016

ło osiemset kilometrów na północ od Norwegii i tysiąc sto kilometrów na południe od bieguna północnego. ${ }^{2}$

W pięciu miejscowościach na głównej wyspie mieszka obecnie dwa tysiące siedemset dwadzieścia sześć osób. ${ }^{3}$ Osiemdziesiąt jeden procent całej populacji mieszka w największym mieście Longyearbyen. $\mathrm{Na}$ wyspach można spotkać ludzi przynależących do czterdziestu sześciu różnych narodowości. Ponad połowa mieszkańców Longyearbyen i Ny-Alesund jest w wieku produkcyjnym, w przedziale między dwudziestym, a czterdziestym czwartym rokiem życia.

Longyearbyen jest miastem najdalej wysuniętym na północ kuli ziemskiej liczącym ponad tysiąc stałych mieszkańców. Z początkiem 2019 roku populacja Longyearbyen liczyła dwa tysiące dwieście piętnaście osób, co stanowi $84 \%$ całej populacji Svalbardu. Miasto zostało założone w 1906 roku przez przedsiębiorcę Johna Munro Longyear'a, który utworzył tu kopalnię węgla kamiennego zarządzaną przez Arctic Coal Company. (Jaskólski, Pawłowski, 2017, s. 171) Obecnie miasto Longyearbyen podzielone jest na dziesięć dzielnic - Sjøområdet, Skjeringa, Sjøskrenten, Elvesletta Nord, Elvesletta Sør, Gruvedalen, Lia, Haugen, Nybyen i Sverdrupbyen.

Fenomen Svalbardu, którym są noce i dnie polarne, wymusza integrację mieszkańców. Bez kontaktów międzyludzkich, człowiek nie mógłby istnieć w społeczeństwie, zaspokoić potrzeb przynależności, poczucia bezpieczeństwa. Dzisiejsza różnorodność mieszkańców pod względem pochodzenia, narodowości, umiejętności, czy pracy sprzyja kreatywności i innowacyjności sprawiając, że życie społeczne i gospodarcze na Spitsbergenie jest bardziej dynamiczne (Bonusiak, 2021). Przestrzenie społeczne pomagają zachować równowagę, wyznaczają strefy otwarte, dostępne dla każdego użytkownika bez względu na rasę, płeć, kulturę i religię, stwarzają możliwość rozwoju społecznego, eliminują poczucie alienacji i wytwarzają więzi społeczne.

Przestrzenie życia publicznego kreowane są spontanicznie lub celowo przy udziale mieszkańców. Posiadają szczególne walory kulturowe, skłaniają użytkowników do refleksji, pozwalają na swobodne wyrażanie poglądów i koncentrują aktywność faktycznego życia publicznego the length of its coastline is 3,587 km. ${ }^{1}$ The islands are located around $800 \mathrm{~km}$ to the north of Norway and around 1,100 km to the south of the North Pole. ${ }^{2}$

The main island's five localities are currently home to 2,726 citizens. $^{3}$ Longyearbyen, the largest town on the archipelago, is home to $81 \%$ of its entire population. We can encounter people belonging to forty-six different nationalities among the people living here. Over half of Longyearbyen's and Ny-Alesund's residents are of working age, aged between 20 and 40.

Longyearbyen is the world's northernmost settlement with over a thousand permanent residents. At the start of 2019, Longyearbyen's population was 2,215 , which is $84 \%$ of Svalbard's overall population. The town was founded in 1906 by entrepreneur John Munro Longyear, who opened a coal mine here that was managed by the Arctic Coal Company (Jaskólski, Pawłowski, 2017, p. 171). At present, Longyearbyen is divided in to ten districts: Sjøområdet, Skjeringa, Sjøskrenten, Elvesletta Nord, Elvesletta Sør, Gruvedalen, Lia, Haugen, Nybyen and Sverdrupbyen.

The phenomenon of Svalbard and its polar nights and days drive its residents to integrate. Without interpersonal contact, people would be unable to exist in a community, to satisfy their need for belonging and sense of safety. Today's diversity of inhabitants in terms of origin, nationality, skills or work promotes creativity and innovation, making the social and economic life in Spitsbergen more dynamic (Bonusiak, 2021) Social spaces aid us in maintaining balance, define areas that are open and accessible to every user regardless of race, sex, culture and religion, and provide an opportunity for social development, eliminating the sense of alienation and fostering social bonds.

Spaces for public life are created either spontaneously or intentionally, with the citizens' participation. They have special cultural value, encourage users to engage in reflection and allow for free expression and act as foci of the actual public life of the town, 
miasta, wyznaczając rytm, tempo, cykl życia na północnym krańcu świata. (Jagiełło-Kowalczyk, Żabicka, 2019)

\section{DZIELNICA GRUVEDALEN BADANIA \\ Opis}

Pierwsze budynki zespołu mieszkaniowego zaprojektowanego przez biuro Louis Lunde wybudowała firma Sandmo \& Svenkerud AS w 2003 roku. Zrealizowany projekt jest jednym z najbardziej wyróżniających się na tle miasta nowoczesnych zabudowań połączonych z przestrzenia publiczną, dostępną nie tylko dla mieszkańców. Projekt zlokalizowano przy ulicy via 232 na północnym stoku góry Sukkertoppen w dolinie Gruvedalen w północno-wschodniej części miasta Longyearbyen. Przestrzenie integracji społecznej, wspólne tarasy do grillowania, place zabaw i wiele innych aspektów społecznych osiedla zostały przemyślane w taki sposób, aby projektowane strefy niemal wtapiały się w zastaną naturę. Najnowsze budynki zostały ukończone w 2016 roku. (Twardowski, 2017)

\section{Funkcja}

Główną i dominującą funkcją zespołu budynków zlokalizowanych w dzielnicy Gruvedalen na zboczu góry Sukkertoppen jest funkcja mieszkaniowa wielorodzinna. Składa się z siedmiu grup obiektów podzielonych na dziewięć, siedem, sześć, pięć i cztery segmenty. Każdy z nich ma dwa mieszkania z osobnymi wejściami z zewnątrz. Przy zespole budynków mieszkaniowych zaprojektowane zostały przestrzenie zewnętrzne sprzyjające integracji mieszkańców, spędzaniu czasu na świeżym powietrzu, w otoczeniu natury i niesamowitych krajobrazów. Znajdują się tutaj place zabaw dla dzieci, miejsca do grillowania, spotkań i odpoczynku. determining the rhythm, tempo and cycle of life on the northern edge of the world. (Jagiełło-Kowalczyk, Żabicka, 2019)

\section{A STUDY OF GRUVEDALEN DISTRICT Overview}

The first buildings of the housing complex designed by Louis Lunde was built by Sandmo \& Svenkerud AS in 2003. The project is one of the most distinctive works of architecture in the town, as it sports modern buildings connected with a public space that is also accessible to non-residents. The design was built at Via 232, on the northern slope of Mount Sukketroppen in the Gruvedalen Valley, in the north-eastern part of Longyearbyen. Social integration spaces, common terraces for grilling, playgrounds and many other social aspects of the complex have been designed so that the zones almost blend into the pre-existing nature. The newest buildings were completed in 2016 (Twardowski, 2017).

\section{Function}

The primary and predominant function of the building complex located in the Gruvedalen district, on the slope of Mount Sukkertoppen, is multi-family housing. The complex comprises seven groups of buildings divided into segments. Each complex of terraced buildings is divided into, nine, seven, six, five or four segments. Each has two apartment units with separate entrances from outside. The building complex also features external spaces that encourage resident integration, spending free time outdoors, surrounded by nature and extraordinary landscapes. The complex also features playgrounds and places

Rys. 1. Położenie zespołu mieszkaniowego w dzielnicy Gruvedalen na tle miasta Fig. 1. Housing development location within Gruvedalen and Longyearbyen

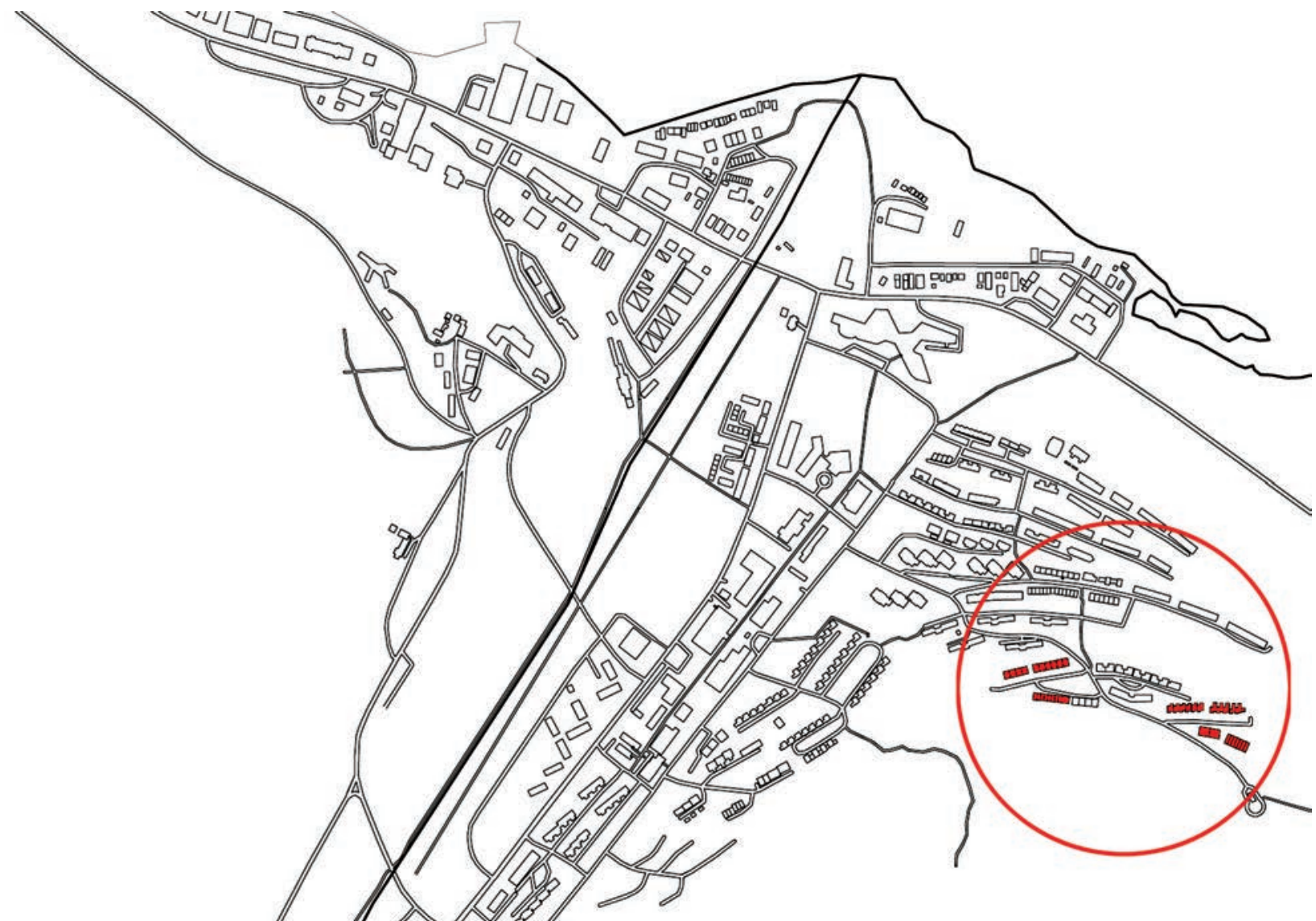




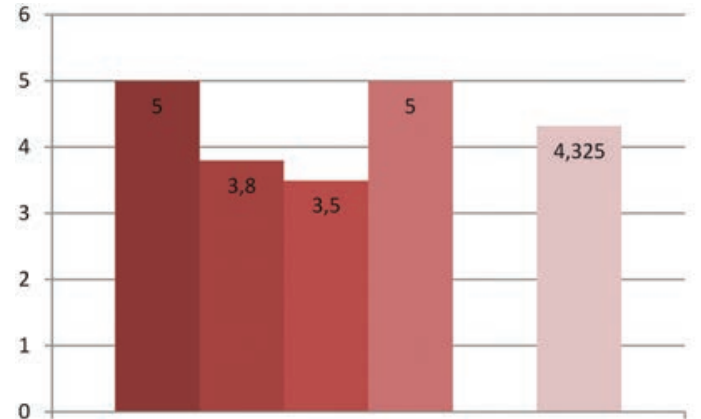

ocena funkcji (od 1 do 6 )

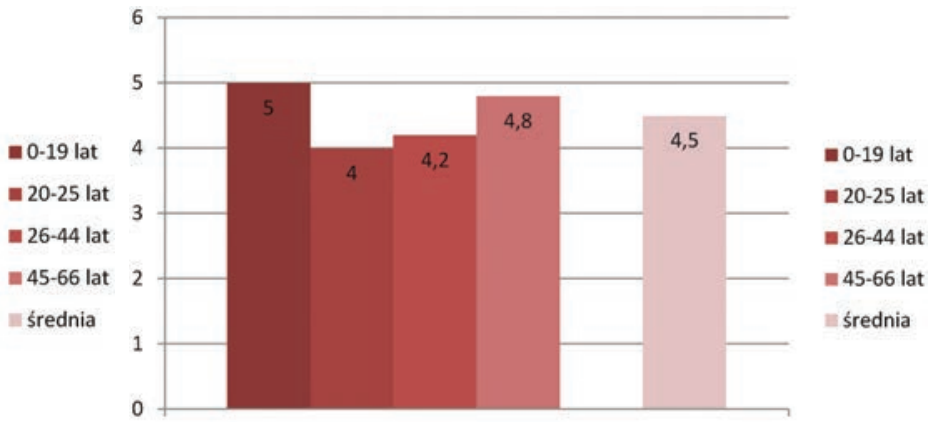

ocena formy architektonicznej (od 1 do 6 )

Tab. 1. Ocena funkcji według ankietowanych / 1. Assessment of function, as rated by respondents

Tab. 2. Ocena formy architektonicznej według ankietowanych / Respondents' ratings of architectural form

mieszkańcy miasta Longyearbyen, także przyjezdni turyści i goście.

W przestrzeniach między budynkami architekci zaprojektowali tarasy dostępne od strony wzgórza. Podczas odpoczynku, zabaw czy wzajemnej integracji można podziwiać otaczającą naturę, lądujące samoloty, czy pływające w zatoce statki wycieczkowe i transportowe.

Zespół cechują proste geometryczne bryły tworzące rytm dzięki powtarzalności form. Każdy element został rozrzeźbiony w podobny sposób, a identyfikacja została nadana dzięki rozróżnieniu kolorystycznemu detali architektonicznych takich jak balustrady.

Bryły zostały wzniesione ponad poziom terenu na tyle wysoko, aby zapewnić nie tylko wentylację między ziemią a poziomem parteru, ale także umożliwić swobodny przepływ wody podczas topnienia dużych ilości śniegu na wiosnę i w lecie. Prostopadłościenne bryły zostały przekryte dachem płaskim, co wyróżnia je na tle otoczenia.

W projekcie zastosowano zarówno pełne jak i ażurowe ściany, dzięki czemu tworzą one ochronę przed wiatrem i bezpośrednim światłem słonecznym docierającym do from the side of the mountain slope and the street located there. The buildings are not fenced in any way, and access to the buildings and spaces around them is provided to all of Longyearbyen's residents, as well as any tourists and guests.

The free spaces between buildings were used by the architects to site terraces that can be accessed from the side of the slope. During rest, play or integration, we can enjoy views of the surrounding nature, aeroplane landings or cruise and transport ships sailing along the bay.

The complex is characterised by simple, geometric massings that form a rhythm due to the repetitiveness of their forms. Every element was sculpted in a similar manner and identification was achieved by the varied colour schemes of architectural details such as railings.

The massings were elevated above ground level to an elevation that allows not only ventilation between the soil and the ground floor, but also free flow of water during the melting of large amounts of snow in

Fot. 3. Przestrzenie wspólne między zabudową mieszkaniową z widokiem na fiord Adventfjorden. fot. Agnieszka Żabicka, 2016 Photo 3. Common spaces between residential buildings overlooking the Adventfjorden Fjord. Photo by Agnieszka Żabicka, 2016

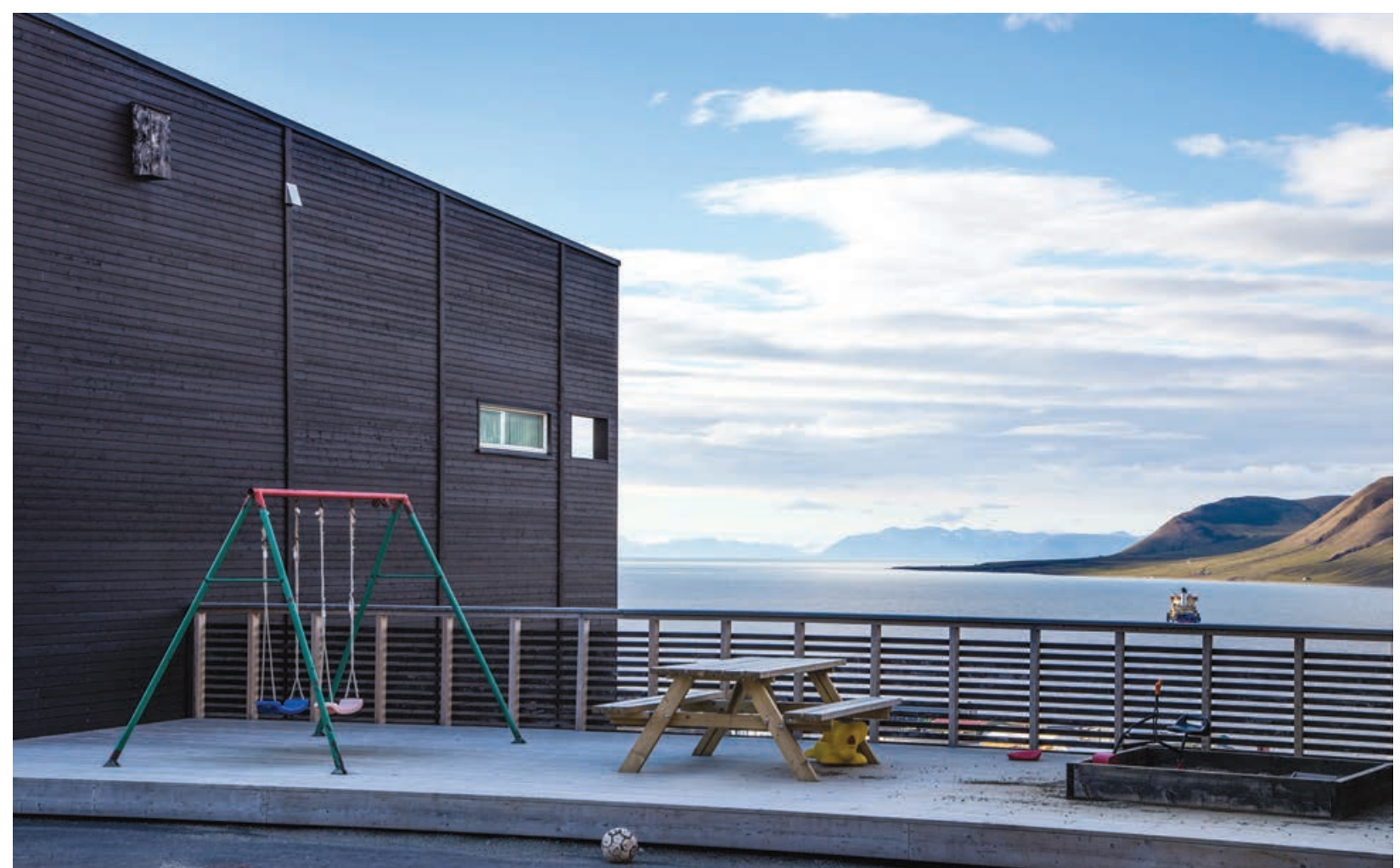


wnętrza. Takie samo rozwiązanie zastosowano w balustradach balkonów i schodów zewnętrznych.

Okna zaprojektowano w różnych formatach. Od strony widokowej duże przeszklenia pokrywają niemal całe ściany. Od strony zbocza znajdują się mniejsze prostokątne okna.

Drewniane ramy, kryjące w sobie kolorowe balkony, połączone są między sobą parterowymi przewiązkami tworzącymi spore tarasy dla mieszkań umiejscowionych na I piętrze.

Analizę oceny formy architektonicznej, jej wpływ na jakość i odbiór przestrzeni społecznej w sześciostopniowej skali (od najniższej 1 do najwyższej 6) na podstawie badań ankietowych obrazuje wykres, tab. 2.

Badanie dotyczące oceny wpływu formy architektonicznej przestrzeni społecznej na jej jakość i pozytywny odbiór wykazało najwyższą ocenę wśród osób z przedziału wiekowego poniżej 19 roku życia, natomiast najniższą wśród grupy 20-25 lat.

\section{Kontekst}

Wielorodzinne zespoły mieszkaniowe wraz z funkcjami towarzyszącymi zlokalizowane zostały w najwyższej części miasta w dolinie Gruvedalen. Najwyżej położone budynki usytuowane są na wysokości 65 m. n.p.m. Wzgórze Sukkertoppen wznoszące się na wysokość 400 m. n.p.m. tworzy delikatne tło dla wyrazistej zabudowy. Latem ciemne bryły wtapiają się w otoczenie spowite delikatną zielenią, zimą wyróżniają się na tle białego śniegu. Niezwykle ważnym aspektem w projektowaniu zabudowy w mieście Longyearbyen jest kontakt z naturą i otaczającym krajobrazem. Układ domów został dostosowany do kierunku zbocza góry. Dotyczy to nie tylko formy zewnętrznej, ale także wewnętrznego układu mieszkań. Od strony północnej z widokiem na dolinę Adventdalen, fiord Advenfjorden i wznoszące się na wysokość 928 m.n.p.m. góry Hiorthfjellet, zostały zaprojektowane pokoje dzienne z balkonami lub tarasami.

Analizę oceny lokalizacji i kontekstu i ich wpływ na jakość i odbiór przestrzeni społecznej w sześciostopniowej skali (od najniższej 1 do najwyższej 6) na podstawie badań ankietowych obrazuje wykres, tab. 3.

Badanie dotyczące oceny wpływu lokalizacji przestrzeni społecznej na jej jakość i pozytywny odbiór wykazało stałą ocenę wśród wszystkich grup wiekowych. spring and summer. The cuboid massings were covered by a flat roof, which gives them a distinctive appearance when contrasted with their surroundings. The buildings feature both solid and openwork walls, which gives protection against wind and direct sunlight in their interiors. The same solution was employed in balcony railings and external stairs.

The windows were designed to be in different formats. From the side with the best views, large glazings fill the walls almost completely. From the side of the slope there are smaller, rectangular windows. Wooden frames that obscure colourful balconies are connected with single-storey masses that form sizeable terraces for first-floor apartment units.

An analysis of the assessment of architectural form and its impact on the quality and reception of social spaces, as rated on a six-point scale (from 1 to 6 ) via a survey, has been shown on a graph in table 2 .

The study concerning assessment of the impact of architectural form of the social space on its quality and positive reception showed that the highest ratings were given by respondents aged below 19, while the lowest were given by respondents aged between 20 and 25 .

\section{Context}

The multi-family housing complexes and their accompanying function were sited in the highest part of the town, in the Gruvedalen Valley. The buildings located the highest are at an elevation of $65 \mathrm{~m}$ above sea level. Mount Sukkertoppen that towers above the terrace houses and has a height of $400 \mathrm{~m}$ above sea level provides a delicate background for the expressive development. In summer, its masses blend into the surroundings which are covered in delicate greenery, while in winter they stand out in the white snow. Contact with nature and the surrounding landscape is a highly essential aspect in designing buildings in Longyearbyen. The layout of houses was adapted to the slope of the mountain. This applies not only to their external form, but also the internal apartment layout. Living rooms with balconies or terraces were designed facing north, with a view of Adventdalen Valley, Adventfjorden Fjord and mount Hjorthfjellet that has a height of $928 \mathrm{~m}$ above sea level.

Tab. 3. Ocena lokalizacji i kontekstu według ankietowanych / Respondents' ratings of the site and context

Tab. 4. Ocena skali przestrzeni społecznych według ankietowanych / Assessment of the scale of the social spaces by respondents

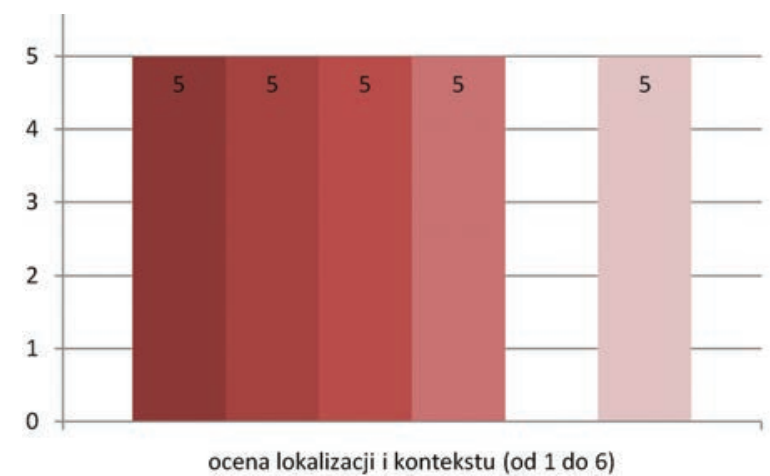

ocena lokalizacji i kontekstu (od 1 do 6)

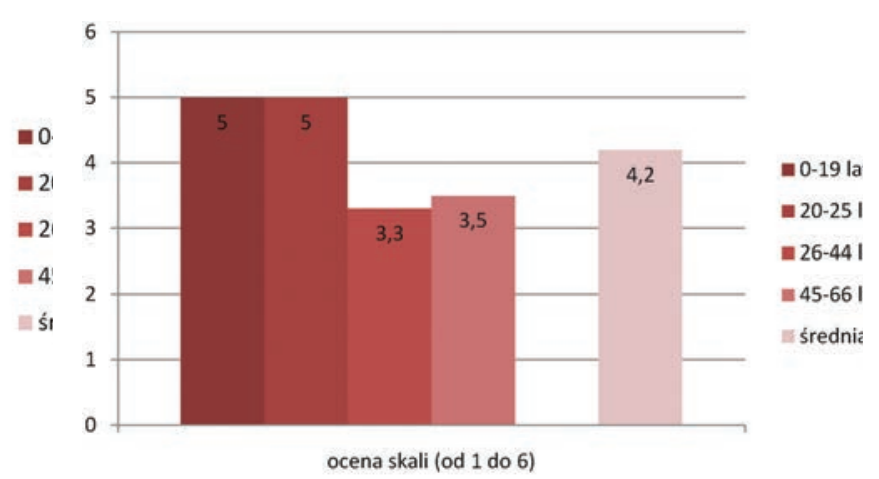




\section{Skala}

Zespół budynków mieszkaniowych wielorodzinnych składa się łącznie z czterdziestu jeden segmentów i osiemdziesięciu dwóch mieszkań. Dwukondygnacyjne budynki zaprojektowane w układzie szeregowym mimo, iż są najwyżej położonymi obiektami na zboczu góry Sukkertoppen, nie dominują nad zabudową miasta i nie przytłaczają jej. Płynnie wtapiają się w tkankę miejską tworząc razem z otaczającymi budynkami spójną całość. Zabudowa dostosowana jest do stromego zbocza, zachowując proporcje i wymiary dostosowane do skali człowieka. Odstępy między poszczególnymi grupami segmentów pozwalają na poczucie przestrzeni i swobodny oddech. Wszystkie elementy układu pozytywnie wpływają na odbiór przestrzeni wewnętrznych i zewnętrznych. Tarasy sprzyjają tworzeniu się przestrzeni społecznych, są otwarte i rozległe.

Analizę oceny skali i jej wpływ na jakość i odbiór przestrzeni społecznej w sześciostopniowej skali (od najniższej 1 do najwyższej 6) na podstawie badań ankietowych obrazuje wykres, tab. 4.

Badanie dotyczące oceny wpływu skali przestrzeni społecznej na jej jakość i pozytywny odbiór wykazało najwyższą ocenę wśród osób z przedziału wiekowego poniżej 25 lat, natomiast najniższą wśród grupy wiekowej 26-44 lata.

\section{Konstrukcja}

Zespół budynków mieszkaniowych zbudowano w lekkiej konstrukcji drewnianej, szkieletowej. Fundamentowanie wykonano za pomocą pali zatopionych w wiecznej zmarzlinie, dzięki czemu konstrukcja całego założenia jest bardzo stabilna. Ściany zewnętrzne pokryte zostały drewnem.

W najnowszych budynkach poziom parteru został podniesiony wyżej niż w przypadku wcześniejszej zabudowy. Takie rozwiązanie pozwoliło na wprowadzenie dodatkowych miejsc postojowych dla samochodów osobowych.

Budynki przykryte zostały dachem płaskim, co świadczy o nowatorskim podejściu opisywanego projektu. Nie jest to popularne rozwiązanie na dalekiej północy ze względu na duże opady śniegu w zimie.

Budynki zostały dostosowane do stromego zbocza, przez co od strony widokowej są wyniesione niemal
An analysis of the assessment of the site, context and their impact on the quality of the social space, as rated on a six-point scale (from 1 to 6 ) in a survey, has been shown in the chart in table 3.

The study concerning the impact of the social space's location on its quality and positive reception showed that respondents of all age groups rated it positively.

\section{Scale}

The complex of multi-family residential buildings consists of a total of forty-one segments and eightytwo apartment units. The two-storey buildings, designed in a terraced layout despite being located the furthest up the slope of Mount Sukkertoppen, are not overbearing in their relation with the town's development. They fluidly blend into the urban fabric and form a cohesive whole with the surroundings buildings. The development is adapted to the steep slope while also maintaining proportions and dimensions suitable to the human scale. The distances between the individual segment groups allow for registering a sense of space and provide breathing room. All of the layout's elements positively affect the reception of internal and external spaces. The terraces are open and extensive, facilitating the formation of social spaces.

An analysis of the assessment of scale and its impact on the quality and reception of the social space, via ratings based on a six-point scale (from 1 to 6) given in a survey, has been presented in the chart in table 4 . The study concerning the impact of the scale of the social space on its quality and positive reception showed that respondents aged below 25 gave the highest ratings, while the lowest ratings were given by people aged 26-44.

\section{Structural system}

The complex of multi-family residential buildings was built using a light wooden structural skeleton. The foundations were designed in the form of piles embedded into permafrost, which is why the entire structure is highly stable. The external walls are clad in wood.

The floor of the first storey is elevated above the soil to provide cross-ventilation and prevent the buildings from becoming flooded by the melting of snow accumulated during winter.

Tab. 5. Ocena konstrukcji według ankietowanych / Assessment of the structural system by the respondents

Tab. 6. Ocena zastosowanych materiałów według ankietowanych / Assessment of the materials by respondents

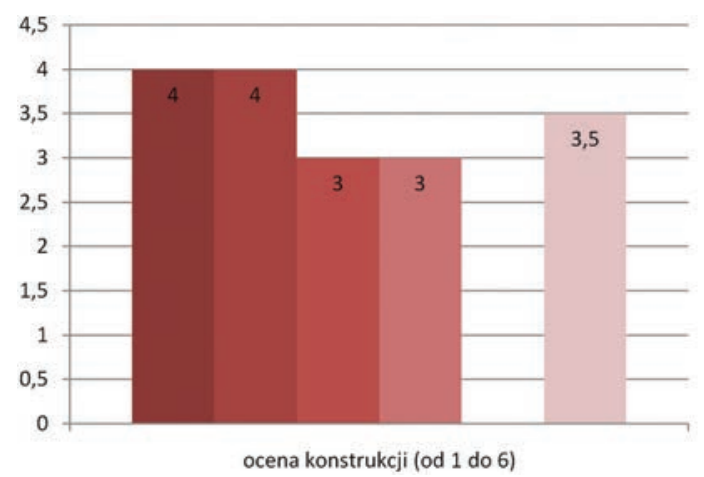

ocena konstrukcji (od 1 do 6)

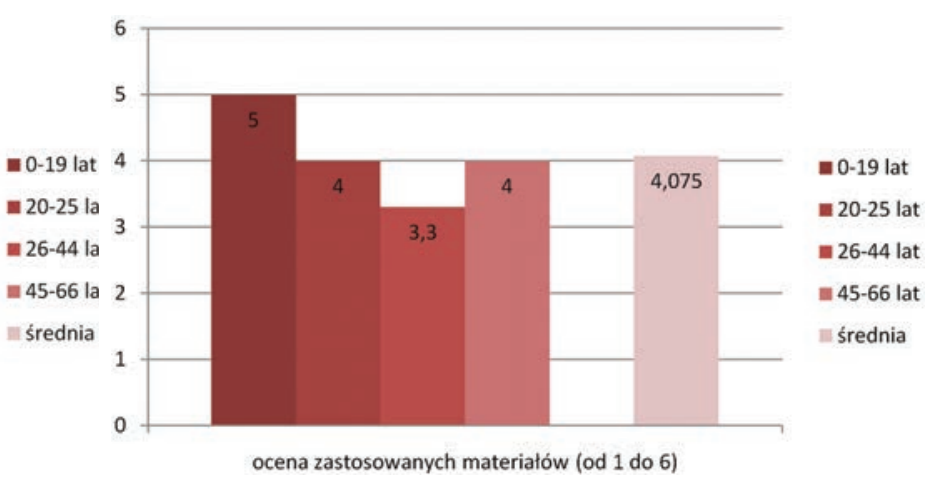


o wysokość całego piętra, podczas gdy od strony frontowej wejście znajduje się na poziomie gruntu, przy zachowaniu szczeliny przewietrzającej pod podłogą.

Analizę oceny konstrukcji i jej wpływ na jakość i odbiór przestrzeni społecznej w sześciostopniowej skali (od najniższej 1 do najwyższej 6) na podstawie badań ankietowych obrazuje wykres, tab. 5.

Badanie dotyczące oceny wpływu konstrukcji przestrzeni społecznej na jej jakość i pozytywny odbiór wykazało najwyższą ocenę wśród osób z przedziału wiekowego poniżej 25 lat, natomiast najniższą wśród grupy powyżej 25 roku życia.

\section{Zastosowane materiały}

Charakterystyczną cechą zespołu mieszkaniowego zlokalizowanego w dolinie Gruvendalen jest bejcowane na ciemny, niemal czarny brąz naturalnego drewna zaprojektowanego w układzie poziomym. Kolorowe balkony również zostały wykonane z drewna i pokryte bejcą.

Analizę oceny zastosowanych materiałów i jej wpływ na jakość i odbiór przestrzeni społecznej w sześciostopniowej skali (od najniższej 1 do najwyższej 6) na podstawie badań ankietowych obrazuje wykres, tab. 6 .

Badanie dotyczące oceny wpływu zastosowanych materiałów przestrzeni społecznej na jej jakość i pozytywny odbiór wykazało najwyższą ocenę wśród osób z przedziału wiekowego poniżej 19 lat, natomiast najniższą wśród grupy 26-44 lata.

\section{Detal i kolor}

Elementem wyróżniającym budynki na tle miasta jest nie tylko ich forma, ale także kolor. W projekcie przeważa ciemne, niemal czarne drewno i akcenty kolorystyczne w postaci wielobarwnych balkonów, które stanowią identyfikację dla mieszkańców. Znajdziemy tu odcienie intensywnych kolorów takich jak żółty, czerwony, pomarańczowy, niebieski, zielony.

Części wspólne utrzymane zostały w neutralnych barwach. Drewno poddane srogim warunkom pogodowym zszarzało i nabrało szlachetnej barwy. Przestrzenie zewnętrzne tworzą całość z otaczającym je środowiskiem naturalnym. Ramy okien utrzymano w białym kolorze kontrastującym z ciemnym drewnem.

Analizę oceny detalu i koloru i ich wpływ na jakość i odbiór przestrzeni społecznej w sześciostopniowej skali

Tab. 7. Ocena detali i koloru przestrzeni społecznych według ankietowanych

Tab. 7. Assessment of the details and colour by respondents

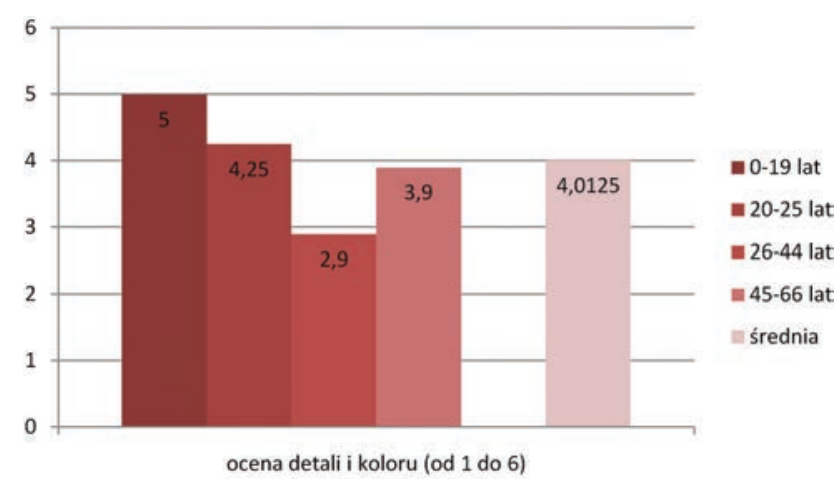

In the newest buildings, the ground-floor level was raised higher than in the case of earlier development. This made it possible to organise additional parking spaces.

The buildings are covered with a flat roof, which shows the innovative character of their design. This is not a popular solution in the far north due to significant snowfall.

The buildings were adapted to the steep slope, which causes them to be elevated by the height of a storey above grade level from the side with the most attractive views, while from the side with the entrances the ground level is almost at grade level, providing a cross-ventilation void under the floor.

An analysis of the assessment of the structural system and its impact on the quality and reception of the social space, via ratings based on a six-point scale (from 1 to 6 ) given in a survey, has been presented in the chart in table 5 .

The study of the assessment of the structural system of the social spaces and its impact on their quality and positive reception showed that respondents aged below 25 gave the highest ratings, while the lowest ratings were by respondents aged above 25 .

\section{Materials}

Natural wood, stained to a dark, almost black brown colour, is a distinctive element of the housing complex in the Gruvedalen Valley. The distinctively coloured balconies were also made and covered with the same material. The narrow boards were designed and mounted to form a horizontal layout.

An analysis of the assessment of the materials and their impact on the quality and reception of the social space, via ratings based on a six-point scale (from 1 to 6 ) in a survey, has been presented in the chart in table 6 .

The study of the assessment of the impact of materials on the social space and its quality and positive reception showed that respondents aged below 19 gave the highest ratings, while respondents aged 26-44 gave the lowest ratings.

\section{Detail and colour}

The element that distinguishes these buildings against the background of the town is not only their form, but also colour. Surrounded by browns, greys, blues and reds, against the background of a green slope, the buildings stand as almost black masses, with coloured balconies. The design is dominated by dark, almost black wood and colourful accents in the form of balconies, which are a form of identification for the residents. Here we can find shades of intense colours like yellow, red, orange, blue and green.

The common spaces are neutrally coloured. Wood, subjected to the harsh weather conditions, has become slightly grey and thus noble. The internal spaces form a whole with the surrounding naturalcoloured earth. The window frames are white so as to contrast with the dark wood.

An analysis of the assessment of details and colour and their impact on the quality and reception of the 
(od najniższej 1 do najwyższej 6) na podstawie badań ankietowych obrazuje wykres, tab. 7.

Badanie dotyczące oceny wpływu detali i koloru przestrzeni społecznej na jej jakość i pozytywny odbiór wykazało najwyższą ocenę wśród osób z przedziału wiekowego poniżej 19 lat, natomiast najniższą wśród grupy 26-44 lata.

\section{Podsumowanie}

Analizę oceny poszczególnych czynników, które mają największy wpływ na jakość i odbiór przestrzeni społecznej na podstawie badań ankietowych obrazuje wykres, tab. 8. Badanie dotyczące oceny wpływu poszczególnych czynników na jakość i pozytywny odbiór przestrzeni społecznej wykazało najwyższy odsetek głosów dla formy architektonicznej (67\% wszystkich głosów), otwarcia na otaczający krajobraz oraz lokalizację i kontekst. Najniższy udział procentowy odpowiedzi uzyskała konstrukcja (15,9\% wszystkich głosów).

\section{DYSKUSJA}

Przestrzenie społeczne na stałe wpisały się w formę urbanistyki miasta, są jego nieodłącznym elementem pozwalającym wykształcić spójną symbiotyczną jednostkę przyjazną użytkownikom. Krajobraz i niespotykana w klimacie umiarkowanym, a tym bardziej równikowym, natura Spitsbergenu przyciąga i magnetyzuje. Niezwykłe zjawisko nocy i dnia polarnego, ekstremalnie niskie temperatury oraz stosunkowo niewielka liczba stałej ludności decydują o potrzebie kontaktu z drugim człowiekiem. Najważniejszym czynnikiem wpływającym na odbiór i kształtowanie przestrzeni społecznych przez mieszkańców jest forma architektoniczna, jej lokalizacja i powiązanie z kontekstem, otoczeniem. Dzięki odpowiednim detalom i zastosowanym materiałom jedne wnętrza są odwiedzane częściej niż inne. To one tworzą wraz z czynnikiem ludzkim przestrzeń, która sprzyja integracji i spędzaniu czasu wspólnie. Przestrzenie wspomagają prawidłowe funkcjonowanie środowiska mieszkaniowego, pozwalają na poczucie bezpieczeństwa rezydentów i odwiedzających.

\section{WNIOSK}

Podsumowując można stwierdzić, że najważniejszym czynnikiem wpływającym na jakość i pozytywny odbiór

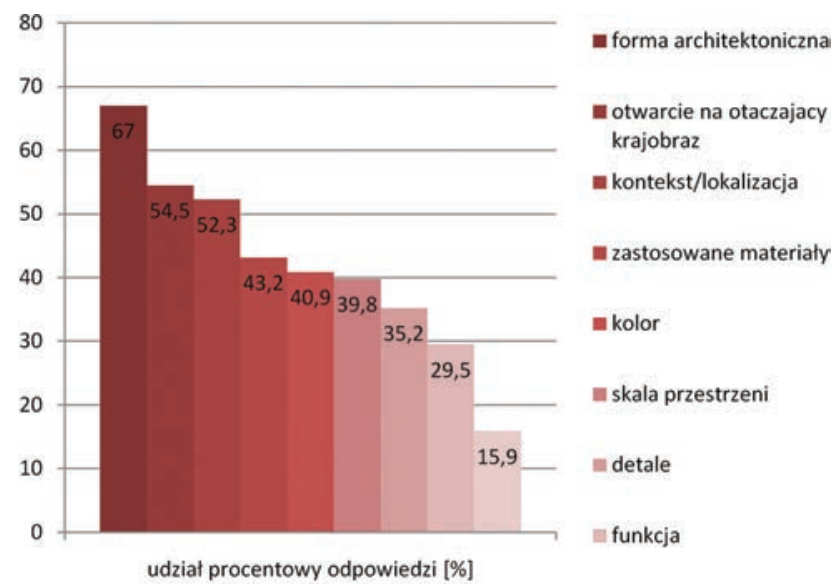

social space, via ratings based on a six-point scale (from 1 to 6 ) in a survey, has been presented in the chart in table 7 .

The study of the assessment of the impact of detail and colour of the social space on its quality and positive reception shows that persons aged below 19 rated it the highest, while persons aged 26-44 rated it the lowest.

\section{Summary}

An analysis of the ratings given to each of the factors that have the greatest impact on the quality and reception of the social space, as based on a survey, has been presented in the chart in table 8 .

The study of the assessment of the impact of each factor on the quality and positive reception of the social space showed that the highest percentage share of responses were in favour of architectural form ( $67 \%$ of all responses), being open towards the landscape and location and context. The structural system received the least amount of favourable ratings $(15.9 \%$ of all responses).

\section{DISCUSSION}

Social spaces have become a fixture of the urban form of the city and have become its inseparable element, allowing for the development of a cohesive, symbiotic unit that is user-friendly. The landscape and nature of Spitsbergen, which cannot be encountered in a temperate or tropical climate, are attractive and magnetic. The extraordinary phenomenon of the polar night and day, extremely cold temperatures and the relatively low permanent population, result in a strong need for interpersonal contact. The most crucial factors that affects the reception and design of social spaces by residents are: architectural form, its location and linkages with the context and surroundings. Due to proper details and materials, some interiors are visited more often than others. It is they who, along with the human factor, form a space that encourages contact, integration and spending time together within a given social group. Such spaces support the correct functioning of the housing environment and enhance the sense of safety among residents and visitors.

\section{CONCLUSIONS}

In conclusion, it can be stated that the most important factor that affects the quality and positive reception of social spaces located adjacent to the housing development in the Gruvedalen district in the town of Longyearbyen, is the architectural form of these urban interiors and of the surrounding development. Another important factor is contact with the extraor-

Tab. 8. Czynniki, które według ankietowanych mają największy wpływ na jakość i pozytywny odbiór przestrzeni społecznej Tab. 8. Factors that the respondents rated as having the highest impact on the quality and positive reception of the social space 
przestrzeni społecznych zlokalizowanych przy zabudowie mieszkaniowej w dzielnicy Gruvedalen w mieście Longyearbyen jest przede wszystkich forma architektoniczna wnętrz urbanistycznych, a także otaczającej zabudowy. Kolejnym wartym podkreślenia czynnikiem jest kontakt z niezwykłą przyrodą Spitsbergenu. To właśnie przede wszystkim dla niej przyjeżdżają tu ludzie z odległych zakątków świata, by zostać na dłużej i delektować się jej pięknem.

Kształtowanie życia publicznego odgrywa nieocenioną rolę w pokonywaniu codziennych przeciwności i trudności związanych z klimatem i warunkami atmosferycznymi miejsca. Mimo ciężkich, surowych i ekstremalnych warunków klimatycznych ludzie nieustannie chcą przybywać na Spitsbergen, żyć, pracować, rozwijać się i kształcić na odległym, północnym krańcu świata. Chcą się integrować z pozostałymi mieszkańcami mimo wielokulturowości i różnorodności ras, języków, charakterów. Kreowane w tej lokalizacji przestrzenie społeczne mają ogromny wpływ na psychikę i funkcjonowanie człowieka w tak ekstremalnych warunkach klimatycznych.

Dzielnica Gruvedalen jest niezwykła ze względu na swoją nowoczesną formę, kolor i rozpościerające się z jej terenów widoki. Prezentuje ona fenomen przestrzeni społecznych zlokalizowanych ponad kołem podbiegunowym północnym, jest przedstawicielem stylu życia Arktyki. Pozytywnie wpływa na integrację miasta, jego mieszkańców, umożliwiając poczucie bezpieczeństwa i przynależności.

\section{PRZYPISY}

1 Coastline lenghts [online]. Dostępny w: world.bymap.org/Coastlines.html [Dostęp: 15.08.2019]

${ }^{2}$ Spitsbergen czy Svalbard [online]. Dostępny w: hornsund.igf.edu.pl/hornsund.old/spitsbergen.html [Dostęp: 15.08.2019]

${ }^{3}$ Statistics Norway. Population of Svalbard [online]. Dostępny w: www.ssb. no [Dostęp: 21.08.2019]

\section{BIBLIOGRAFIA}

[1] Bonusiak, G., 2021. Sustainability : Development of Ecotourism in Svalbard as Part of Norway's Arctic Policy, nr 13 (2) : 962.

[2] Coastline lenghts [online]. Dostępny w: world.bymap.org/Coastlines.html [Dostep: 15.08.2019]

[3] Jagiełto-Kowalczyk M., Żabicka A., 2019. International Journal of Psychosocial Rehabilitation: The Svalbard Church in Longyearbyen, Spitsbergen, as an example of a social space in an area with an extremely cold climate, vol. 21 iss. 1, str. 227-242.

[4] Jaskólski M., Pawłowski Ł., 2017. Turystyka Kulturowa: Turystyka kulturowa na Spitsbergenie - stan obecny i możliwości rozwoju, nr 2/2017 (marzec-kwiecień 2017), Wrocław, str.171.

[5] Petrov A., Vlasova T., 2016. Sustainability: Towards an Arctic Sustainability Monitoring Framework, nr $13: 4800$.

[6] Roberts P., Paglia E., 2016. Social Studies of Science: Science as national belonging: The construction of Svalbard as a Norwegian space, 46, str. 894-911. [7] Schneider-Skalska G., 2012. Środowisko Mieszkaniowe - Housing Environment : Funkcje i formy przestrzeni społecznej, 10/2012, Kraków: Wyd. Katedry Kształtowania Środowiska Mieszkaniowego, str. 6-9.

[8] Spitsbergen czy Svalbard [online]. Dostępny w: hornsund.igf.edu.pl/hornsund.old/spitsbergen.html [Dostęp: 15.08.2019]

[9] Statistics Norway. Population of Svalbard [online]. Dostępny w: www.ssb. no [Dostęp: 21.08.2019]

[10] Szupryczyński, J., 1968. Niektóre zagadnienia czwartorzedu na obszarze Spitsbergenu, Warszawa: Państwowe Wydawnictwo Naukowe, str. 8.

[11] Twardowski, M., 2017. ARCH: O Spitsbergenie tu mowa. Część II, nr 2 (40), Warszawa: Stowarzyszenie Architektów Polskich SARP, str. 102-114. dinary wildlife of Spitsbergen. It is because of this wildlife that people from far sides of the world come here, to stay for longer and take in its beauty. The shaping of public life plays an invaluable role in overcoming everyday adversities and difficulties associated with place-based climate and atmospheric conditions. Despite difficult, harsh and extreme climate conditions, people constantly want to come to Spitsbergen to live, work, grow and learn in this distant, northern fringe of the world. They want to integrate with other residents despite multiculturalism and the diversity of races, languages and personalities. The social spaces designed in this area have an immense impact on human psychology and functioning in such extreme climate conditions. The Gruvedalen district is extraordinary due to its modern form, colour and the views it offers. It presents the phenomenon of social spaces located beyond the Arctic Circle and is representative of the Arctic lifestyle. It positively affects the integration of the town and its residents, enhancing their sense of safety and belonging.

\section{ENDNOTES}

1 Coastline lenghts [online]. Accessed: world.bymap.org/Coastlines.html [Access: 15.08.2019]

2 Spitsbergen czy Svalbard [online]. Accessed: hornsund.igf. edu.pl/hornsund.old/spitsbergen.html [Access: 15.08.2019] ${ }^{3}$ Statistics Norway. Population of Svalbard [online]. Accessed: www.ssb.no [Access: 21.08.2019]

\section{REFERENCE}

[1] Bonusiak, G., 2021. Sustainability : Development of Ecotourism in Svalbard as Part of Norway's Arctic Policy, nb 13 (2) 962.

[2] Coastline lenghts [online]. Accessed: world.bymap.org/Coastlines.html [Access: 15.08.2019]

[3] Jagiełło-Kowalczyk M., Żabicka A., 2019. International Journal of Psychosocial Rehabilitation: The Svalbard Church in Longyearbyen, Spitsbergen, as an example of a social space in an area with an extremely cold climate, vol. 21 iss. 1, p. 227-242. [4] Jaskólski M., Pawłowski Ł., 2017. Turystyka Kulturowa: Turystyka kulturowa na Spitsbergenie - stan obecny i możliwości rozwoju, nb 2/2017 (marzec-kwiecień 2017), Wrocław, p.171.

[5] Petrov A., Vlasova T., 2016. Sustainability: Towards an Arctic Sustainability Monitoring Framework, nb 13: 4800.

[6] Roberts P., Paglia E., 2016. Social Studies of Science: Science as national belonging: The construction of Svalbard as a Norwegian space, 46, p. 894-911.

[7] Schneider-Skalska G., 2012. Środowisko Mieszkaniowe - Housing Environment: Funkcje i formy przestrzeni społecznej, 10/2012, Kraków: Wyd. Katedry Kształtowania Środowiska Mieszkaniowego, p. 6-9.

[8] Spitsbergen czy Svalbard [online]. Accessed: hornsund.igf. edu.pl/hornsund.old/spitsbergen.html [Access: 15.08.2019]

[9] Statistics Norway. Population of Svalbard [online]. Accessed: www.ssb.no [Access: 21.08.2019]

[10] Szupryczyński, J., 1968. Niektóre zagadnienia czwartorzedu na obszarze Spitsbergenu, Warszawa: Państwowe Wydawnictwo Naukowe, p. 8.

[11] Twardowski, M., 2017. ARCH: O Spitsbergenie tu mowa. Czesść II, nb 2 (40), Warszawa: Stowarzyszenie Architektów Polskich SARP, p. 102-114. 